\title{
Research on Correlation between Oral Performance and Sources and Disciplines of University Students
}

\author{
Yongyan Song \\ School of Foreign Languages, Jilin Agricultural University, Changchun 130118, China \\ 1012932249@qq.com
}

Keywords: Oral performance; Source; Discipline; Correlation; Implication

\begin{abstract}
This research adopts questionnaire and quantitative analysis to explore the relationship between oral performance and sources of university students and the relationship between oral performance and disciplines of university students by using SPSS software package to analyze the students' oral performances and data collected from questionnaire and to do independent sample T-test. The research results indicate that there is no significant difference between oral performance and sources but there is very significant difference between oral performance and disciplines. This research analyzes the reasons and offers implications to improve students' oral level and oral teaching quality.
\end{abstract}

\section{Introduction}

In the 70s of last century, the researches done by many scholars transferred from external factors such as teaching methods, textbooks to the learners' internal factors including language learning anxiety, age, gender, interests, motivation, attitude, personality, source, discipline etc. Among so many learners' inner factors, some domestic experts and scholars have done a lot of researches on the relationship between English standard, English level and genders, sources and disciplines. They have drawn different conclusions. For example, Yuan Jieting \& Gao Zhiqiang [1] have done the research on the relationship between discipline (art and science) and PRETCO-A, CET4 and CET6. Their research result showed there was significant difference between English achievement of art students and that of science students, and English achievement of art students is much higher than that of science students. Yuan Jieting \& Gao Zhiqiang [2] have also done the research on the relationship between source (city and country) and English achievement. Their research result indicated that the English achievement of urban students was higher than that of rural students. Li Zaixing \& Hu Jie et al [3] have studied CET4 scores by using statistical method. The result is that there is difference in CET4 scores of urban students and rural students and the scores of urban students is higher than that of rural students; there is difference in CET4 scores of art students and sciences students and the scores of art students is higher than that of science students. The findings of Tian Yong \& Zeng Huailin [4] is the English achievement of art students is higher than that of science students in their study on the difference between the English achievement of art students and that of science students. The findings of Mao Hongjuan \& Qiu Zhequan [5] is that there is difference between CET4 scores of art students and that of science students and the average score of art students is higher than that of science students. From what have been reviewed we can see that these experts and scholars have done the researches on the relationships between the factors (source and discipline) and English comprehensive achievements (mainly CET4 and CET6) and overall English standard. However, a small number of experts and scholars have done the researches on the relationship between English achievement of one subject (listening, speaking, reading, writing or translating) and these factors (source and discipline). Therefore, this research is on the relationship between source and oral performance, and discipline and oral performance. This research also analyzes the reasons and offers some implications to improve oral teaching quality.

\section{Research Method}

Research Subjects. The subjects in this research are $102 \mathrm{C}$ level postgraduates in grade 2014 from 
Jilin Agricultural University. The natural status of the subjects is in Table 1, see Table 1.

Table 1 Natural status of the subjects

\begin{tabular}{|c|c|c|c|c|c|c|}
\hline \multirow{2}{*}{ Item } & \multicolumn{2}{|c|}{ gender } & \multicolumn{2}{c|}{ source } & \multicolumn{2}{c|}{ discipline } \\
\cline { 2 - 7 } & male & female & city & country & art & science \\
\hline $\mathrm{N}$ & 55 & 47 & 51 & 51 & 52 & 50 \\
\hline Proportion (\%) & 53.92 & 46.08 & 50.00 & 50.00 & 50.98 & 49.02 \\
\hline
\end{tabular}

Research Tools. The research tools include questionnaire of the natural status of the subjects: gender, source and discipline; electronic version of oral test paper written by the team members including two types: reading aloud and answering questions and the total score is 20 points; oral grading criteria [6].

Research Problems. This research will solve two problems: (1) What is the correlation between oral performance and sources? (2) What is the correlation between oral performance and disciplines?

Data Collection and Analysis. The teachers from the research team delivered the questionnaires to the subjects in class, and the subjects filled in the questionnaires on the spot, then the teachers collected them in time. Among 111 questionnaires delivered, 9 were removed because of carelessly and incorrectly filling in, and 102 were effective. The effective rate is $91.89 \%$. The subjects took oral test by computer in the multimedia language lab. The subjects finished the test according to the requirement and all language activities were automatically stored in the computer system for grading. In order to ensure the reliability and stability of subjects' oral scores, the three teachers from the research team graded the oral performance of each subject and the average score is the oral performance of each subject. At last, the data from the questionnaire and oral performance were put into computer for descriptive analysis and independent sample T-test by using SPSS software package.

\section{Results and Discussion}

Correlation between Oral Performance and Sources. Descriptive analysis and independent sample T-test of the relationship between oral performance and source of the subjects are done by using SPSS software package. The result is shown in Table 2, see Table 2.

Table 2 Descriptive analysis and independent sample T-test of the relationship between oral performance and sources of the subjects

\begin{tabular}{|c|c|c|c|c|c|c|}
\hline \multirow{2}{*}{ item } & \multirow{2}{*}{$\mathrm{N}$} & \multicolumn{3}{|c|}{ oral performance } \\
\cline { 3 - 6 } & & & $\mathrm{M}$ & $\mathrm{SD}$ & $\mathrm{t}$ & $\mathrm{p}$ \\
\hline \multirow{2}{*}{ source } & city & 51 & 10.508 & 2.641 & \multirow{2}{*}{1.250} & \multirow{2}{*}{0.214} \\
\cline { 2 - 5 } & country & 51 & 9.837 & 2.774 & \\
\hline \multicolumn{2}{|c|}{ total N } & 102 & 10.173 & 2.716 & & \\
\hline
\end{tabular}

As is shown in table 2, the average score of urban students' oral performance is 10.508 and that of rural students' oral performance is 9.837 . The average oral performance of urban students is 0.671 points higher than that of rural students, which indicates there is difference between the oral performance of urban students and that of rural students. However, the result of independent sample T-test shows that there is no significant difference between the oral performance of urban students and that of rural students $(\mathrm{t}=1.250 ; \mathrm{p}=0.214>0.05)$. The reasons may be that English learning environment and atmosphere of the country is inferior to that of the city; hardware facilities and teaching staff are different between city and country; there are differences between the cultural level and education received of urban students' parents and that of rural students' parents etc.[7]. There are so many factors leading to the results that English standard of urban students is higher than that of rural students. However, whether they are rural students or urban students, they have the clear 
aim of going to their own ideal universities, so they focused more on the written tests instead of spoken tests in high school. Therefore, both the oral performance of urban students and that of rural students are not high. After entering universities, both the rural students and urban students aren't willing to take part in classroom activities in class, especially $\mathrm{C}$ level students because of low English level, they are afraid of speaking English and being laughed at by the teacher and classmates in class. Thus, there is no significant difference between the oral performance of rural students and that of urban students.

Correlation between Oral Performance and Disciplines. Descriptive analysis and independent sample T-test of the relationship between oral performance and discipline of the subjects are done by using SPSS software package. The result is shown in Table 3, see Table 3.

Table 3 Descriptive analysis and independent sample T-test of the relationship between oral performance and disciplines of the subjects

\begin{tabular}{|c|c|c|c|c|c|c|}
\hline \multirow{2}{*}{ item } & \multirow{2}{*}{$\mathrm{N}$} & \multicolumn{3}{|c|}{ oral performance } \\
\cline { 3 - 6 } & & & $\mathrm{M}$ & $\mathrm{SD}$ & $\mathrm{t}$ & $\mathrm{p}$ \\
\hline \multirow{2}{*}{ discipline } & art & 52 & 11.292 & 2.150 & \multirow{2}{*}{$4.662 * * *$} & \multirow{2}{*}{0.000} \\
\cline { 2 - 6 } & engineering & 50 & 9.008 & 2.770 & \\
\hline \multicolumn{2}{|c|}{ total N } & 102 & 10.173 & 2.716 & & \\
\hline
\end{tabular}

Note $: * \mathrm{p}<0.05, * * \mathrm{p}<0.01, * * * \mathrm{p}<0.001$ 。

As is shown in table 3, the average score of art students' oral performance is 11.292 and that of engineering students is 9.008 . The average score of art students' oral performance is 2.284 points higher than that of engineering students, which indicates there is difference between the oral performance of art students and that of engineering students. The result of independent sample T-test shows that there is very significant difference between the oral performance of art students and that of engineering students $(\mathrm{t}=4.662 ; \mathrm{p}=0.000<0.001)$. The reasons may be $(1)$ the proportion of boy students majoring in engineering is much higher than that of girl students, and the proportion of girl students majoring in art is much higher than that of boy students. Some researchers have drawn the conclusion that the differences in gender result in very significant difference in foreign language learning and the foreign language achievement of girl students is higher than that of boy students. From this we can infer that English achievement of art students is higher than that of engineering students. (2)The specialties that engineering students major in includes mechanical, civil engineering, electrical engineering, automobile, electronics and information, roads and bridges, chemical and pharmacy etc. [8]. Engineering students have carefully logical thinking, concentrate on what they doing, and aren't good at verbal expression. However, art students are good at learning Chinese, English, history, geography etc. so most art students are erudite and informed, have wide vision, have larger vocabulary and have strong ability of organizing language and oral expression. Therefore, the oral performance of art students is significantly higher than that of engineering students.

\section{Conclusion and Implication}

The natural status of the subjects and oral performances of the subjects are analyzed by suing SPSS software package to explore the correlation between source, discipline and oral performance in the case of descriptive analysis and independent sample T-test. The result shows that there is no significant difference between source and oral performance, but there is very significant difference between discipline and oral performance. The author also analyzes the reasons.

This research enriches the research results of related factors affecting oral performance and at the same time offers implications to improve oral teaching quality: (1) Collaborative learning can create a relaxed and communicative environment. Johnson D. W. \& Johnson R. T. (1994) [9] in the Cooperative Learning Center of University of Minnesota found that mutual influence of cooperative 
learning and cooperative environment can easily stimulate students' motivation compared with that of individual, competing environment. Therefore, in the oral teaching class, the teacher can divide the students into several study groups based on their different sources, achievements and different gender, which will make students communicate in a harmonious and relaxed atmosphere and their oral learning effect will be better [10]. (2) Appreciation education can create a good learning environment. Teachers should strive to create a student-centered classroom atmosphere and a harmonious environment, and organize a variety of oral classroom activities such as group discussion, role play, speech and pair work etc. to stimulate students' enthusiasm. Whether the students perform well or not at the beginning, teachers should praise them and encourage them to eliminate their psychological fear and anxiety. Appreciation education can increase students' self-confidence [11], and improve students' English achievement especially oral performance.

\section{Acknowledgments}

This paper is supported by Jilin Provincial social science funds (2014 WY18)

\section{References}

[1] J.T.Yuan and Z.Q.Gao: Students' English Entrance Score Difference Analysis of Art students and Science Students [J]. Campus English, (2005) No.2, pp.38-39. (In Chinese)

[2] J.T.Yuan and Z.Q.Gao: Quantitative Analysis of Influence of Source Differences on Students' English Achievement [J]. Intelligence, (2015) No.1, pp.316-317. (In Chinese)

[3] Z.X.Li, J.Hu et al.: Statistical Analysis for CET4 [J]. MAHEMATICAL THEORY AND APPLICATIONS, Vol.32 (2012) No.1, pp. 99-104. (In Chinese)

[4] Y.Tian and H.LZeng: The Difference between Art Learners' English Performance and Science Learners' English Performance [J]. JOURNAL OF HUNAN INDUSTRY POLYTECHNIC, (2002) No. 3, pp. 46-47. (In Chinese)

[5] H.J.Mao and Z.Q.Qiu: A Study on Non-English Major College Students' English Learning Strategies [J]. JOURNAL OF JIANGSUOLYTECHNIC UNIVERSITY, (2008) No.3, pp.104-107. (In Chinese)

[6] Information on http://wenku.baidu.com/view/848846ef6294dd88d0d26b65.html.

[7] B.L.Zhang: A Study On The Differences And Intervention Between The English Study Of Senior Students From The Country And Those From The City [D]. (MS., Suzhou University, China 2008), pp. 11-13. (In Chinese)

[8] C.M.Dai: Exploration on Oral Communicative Teaching for Engineering Students in Secondary Vocational School [D]. (MS., Hebei Normal University,2009), pp.3-4. (In Chinese)

[9] Johnson D. W. \& Johnson R. T. Learning Together and Alone: Cooperative, Competitive, and Individualistic Learning. (4th ed). Needham Heights, Massachusetts: Allynand Bacon. 1994.

[10]T.Liang: Strategies of Anxiety in Spoken English Teaching [J]. Cultural Education, (2013) No.1, pp.61-62. (In Chinese)

[11] M.Y.Wu: Research on English Oral Anxiety of Rural Students in Local Art School [J]. Journal of Guangxi College of Education, Vol. 137(2015) No.3, pp. 64-66. (In Chinese) 